УДК 657.471.12:658.5:005.932.5

DOI: $10.15673 /$ fie.v10i3.1063

\author{
Васьковська К.О. \\ кандидат економічних наук, старший викладач \\ кафедра обліку та аудиту \\ E-mail: v.caterin17@gmail.com \\ Пчелянська Г.Б. \\ старший викладач \\ кафедра обліку та аудиту \\ E-mail: gaya_od@ukr.net \\ Кохан 0.0. \\ магістрант \\ кафедра обліку та аудиту \\ Одеська національна академія харчових технологій \\ вул. Канатна, 112, м. Одеса, Україна, 65039 \\ E-mail: lenochka.kohan@gmail.com
}

\title{
ОБЛІК РОЗРАХУНКІВ 3 ОПЛАТИ ПРАЦІ В СИСТЕМІ УПРАВЛІННЯ ПІДПРИЄМСТВОМ
}

\begin{abstract}
У статті викладено та розглянуто особливості бухгалтерського обліку розрахунків з оплати праці працівникам підприємства з метою удосконалення системи обліку, а саме поліпшення організації обліку розрахунків з оплати праці з метою вирішення актуальних питань розвитку бізнесу шляхом прийняття дієвих управлінських рішень.

Вагому частку в собівартості продукції займають саме витрати на оплату праці працівникам підприємства. Для ефективного розвитку підприємству необхідно детально вивчати структуру цих витрат, стимулювати зацікавленість працівників (мотиваційні заходи) для підвищення продуктивності їх праці, контролювати темпи підвищення розміру заробітної плати по відношенню до росту продуктивності праці, впровадження автоматизації облікового, аналітичного та контрольного процесу обліку розрахунків з оплати праці.
\end{abstract}

Ключові слова: облік, заробітна плата, витрати на оплату праці, внутрішня управлінська звітність, мотивація працівників, автоматизація процесу.

This work is licensed under a Creative Commons Attribution 4.0 International License http://creativecommons.org/licenses/by/4.0/

Постановка проблеми та її зв'язок з важливими науковими та практичними завданнями. При прийнятті результативних управлінських рішень велику роль відіграє достовірна, своєчасна інформація щодо обсягу витрат для оплати праці працівників підприємства. При формуванні собівартості продукції потрібно приділяти значну увагу обліку розрахунків 3 оплати праці та характеру їх змін на підприємстві, оскільки видатки на оплату праці займають чималий розмір в сумарній вартості статей калькуляції повної собівартості продукції. Ефективне управління та постійний контроль розміру витрат на оплату праці $\epsilon$ надзвичайно важливим в сучасний умовах конкурентної боротьби щодо пошуку шляхів зниження собівартості виготовленої продукції.

Аналіз останніх публікацій по проблемі. Вивчення особливостей обліку розрахунків 3 оплати праці, питання організації та удосконалення обліку праці на підприємстві знайшли своє відображення в роботах сучасних вчених, а саме: Ф.Ф. Бутинець, Р.Ф. Бруханський, П.М. Гарасим, С.Ф. Голов, Г.П. Журавель, І.О. Лепьохіна, О.К. Лишиленко, М.С. Пушкар, І.Б. Садовська, Н.М.Ткаченко, П.Я. Хомин, Л.М. Черчик, та ін. Проте дослідження структури витрат на оплату праці в управлінні підприємством є особливо актуальними в сучасних умовах функціонування підприємств.

Формулювання цілей дослідження. Основною метою статті є вивчення, шляхом дослідження, питань організації обліку розрахунків з оплати праці працівникам підприємства 3 метою зниження рівня даних витрат, зменшення тиску на розмір повної собівартості продукції та покращення на підприємстві обліку розрахунків з оплати праці для прийняття результативних рішень в системі управління ним.

Виклад основних результатів та їх обгрунтування. Провідне місце у бухгалтерському обліку займає точність відображення інформації щодо обліку оплати праці що значно впливає на кінцевий фінансовий результат діяльності (прибуток) підприємства.

П(С)БО № 26 «Виплати працівникам» визначає методологічні засади розкриття в бухгалтерському обліку інформації про виплати працівникам, та іiі відображення у фінансовій звітності [1].

Для обліку оплати праці на підприємстві використовують такі документи: оборотно-сальдова відомість по рахунку; табель обліку використання робочого часу; платіжна відомість; штатний розпис; особисті справи працівників; нормативні та законодавчі документи щодо обліку (нарахування, відрахувань 
та утримань) заробітної плати, лікарняних та відпускних; особовий рахунок; розрахункова відомість; трудові договори та контракти; а також касова книга, баланс та головна книга. Необхідно наголосити про правильність заповнення первинних та зведених документів, які є вагомим додатком до регістрів обліку (синтетичного та аналітичного) для своєчасності їх оформлення.

Аналіз публікацій показав, що автори виділяють п’ять груп поміж усіх виплат працівникам облікового складу [2]:

- поточні виплати (обов'язковість їх сплати на протязі одного календарного року після закінчення періоду здійснення);

- виплати по закінченню трудової діяльності працівників;

- виплати при звільненні працівників;

- виплати інструментами власного капіталу підприємства;

- інші довгострокові виплати.

Проведення аналізу таких основних показників обсягу заробітної плати та ефективності праці $€$ необхідним фактором результативного функціонування системи бухгалтерського (фінансового) обліку та внутрішнього аудиту на підприємстві:

- чисельність працівників, їх кваліфікація; дино-дні);

- облік робочого часу (людино-години, лю-

- кількість і якість виробленої продукції, наданих послуг;

- розмір фонду оплати праці за категоріями працівників, видами нарахувань, заохочувальних премій, щорічних сум відпускних;

- розмір відрахувань до фондів соціального страхування, тощо.

Ці показники використовуються для розрахунку економічних даних, таких як рівень забезпеченості підприємства робочою силою та середнього розміру заробітку працівників, продуктивності їх праці і фондовіддачі.

Організація бухгалтерського обліку оплати праці на підприємстві регламентується вимогами Закону України «Про оплату праці» на підставі законодавчих та інших нормативних актів, генеральної угоди на державному рівні, галузевих, регіональних угод, колективних і трудових договорів [3].

Відповідно до Закону України «Про оплату праці», підприємства в колективному договорі 3 дотриманням норм і гарантій, передбачених законодавством, встановлюють форми й системи оплати праці, розцінки, тарифні сітки, схеми посадових окладів, умови запровадження і розміри надбавок (за високу професійну (фахову) майстерність, за високі досягнення в праці, за вислугу років, за виконання особливо важливої чи особливо термінової роботи, тощо), доплат (за суміщення професій (посад); за розширення зони обслуговування або збільшення обсягу виконуваних робіт; за виконання обов'язків тимчасово відсутнього працівника; за роботу у важких, шкідливих і небезпечних умовах праці; за інтенсивність пра- ці; за роботу в понаднормовий час; за роботу в нічний час; за роботу у вихідні і святкові дні; на період освоєння нових норм трудових затрат; за керівництво бригадою, підсобним господарством тощо), премій, винагород та інших заохочувальних, компенсаційних і гарантійних виплат $[3,11]$.

На підприємстві винагорода за працю визначається кількістю та якістю виконаної кожним працівником роботи і обумовлюється кінцевими показниками фінансово-господарської діяльності підприємства. В сучасних реаліях бізнесу заробітна плата посідає одне 3 найголовніших аспектів в видатках підприємства. Тому керівництво підприємства намагається максимально зменшити ці витрати, наслідком чого є те, що, нажаль, багато людей в Україні отримують мінімальну заробітну плату.

Мінімальна заробітна плата - це законодавчо встановлений розмір оплати праці за виконану працівником просту (некваліфіковану) роботу за місячною (погодинною) нормою оплати праці [3].

Мінімальна заробітна плата виступає соціальною гарантією для населення країни, носить державний характер та $є$ зобов'язаннями до виконання для роботодавців (фізичних та юридичних (підприємства всіх форм власності, компанії, організації, тощо) осіб, що використовують найману працю незалежно від форм і систем оплати праці їх працівників. Заохочувальні, компенсаційні виплати, доплати, премії та надбавки не включаються до складу мінімальної заробітної плати.

Також на ряду з мінімальною заробітною платою є встановлення розміру прожиткового мінімуму. Сума прожиткового мінімуму на поточний рік встановлюється Кабінетом Міністрів України та затверджується Верховною Радою України і регламентується законом України «Про Державний Бюджет» на поточний рік.

Порядок обчислення оплати праці персоналу визначають за різними системами та формами оплати праці з урахуванням особливостей діяльності підприємства. Щоб поліпшити систему бухгалтерського обліку потрібно покращити систему первинного обліку.

Так, Ф.Ф. Бутинець при вивченні теорії бухгалтерського та фінансового обліку заробітної плати, надає визначення терміну «заробітна плата», характеризує рахунок 66 «Розрахунки за виплатами працівникам», розкриває документування господарських операцій, відображення операцій на рахунках бухгалтерського обліку, тощо [4].

На промислових підприємствах для обліку заробітної плати планом рахунків передбачено використання рахунку 66 «Розрахунки за виплатами працівникам». Цей рахунок $є$ активно-пасивний. Саме на цьому рахунку відбувається узагальнення інформації про розрахунки 3 персоналом, як облікового, так $\mathrm{i}$ необлікового складу, підприємства 3 оплати праці (за всіма видами заробітної плати, премій, допомоги тощо), а також розрахунки за неодержану персоналом у встановлений термін суму з оплати праці (розрахунки з депонентами) [5]. 
За дебетом рахунку 66 «Розрахунки за виплатами працівникам» відображається виплата основної та додаткової заробітної плати, премій, допомоги по тимчасовій непрацездатності тощо; вартість одержаних матеріалів, продукції та товарів у рахунок заробітної плати (погашення заборгованості перед працівниками за іншими виплатами); утримання податку 3 доходів фізичних осіб, військовий збір, та інші утримання 3 виплат працівникам. За кредитом рахунку 66 «Розрахунки за виплатами працівникам» відображаються нарахована працівникам підприємства основна та додаткова заробітна плата, премії, допомога по тимчасовій непрацездатності, інші належні до нарахування працівникам виплати [5].

Згідно Інструкції про застосування Плану рахунків бухгалтерського обліку активів, капіталу, зобов'язань і господарських операцій підприємств i організацій рахунок 66 «Розрахунки за виплатами працівникам» має такі субрахунки [5]:

- 661 «Розрахунки за заробітною платою»;

- 662 «Розрахунки 3 депонентами»;

- 663 «Розрахунки за іншими виплатами».

I.Б. Садовська у своєму підручнику чітко виклала методику синтетичного та аналітичного обліку розрахунків з оплати праці на підприємствах різних форм власності [6].

Одним 3 основних моментів системи бухгалтерського обліку $€$ складання внутрішньоуправлінської звітності, яка затверджується наказом керівника підприємства. Цікаву думку на рахунок звітності висловив П.М. Герасим, звітність - це система взаємопов'язаних показників, що характеризують умови та результати діяльності підприємства [7].

Працівники бухгалтерії складають звітність на основі підсумкових показників щодо розрахунків оплати праці наприкінці звітного періоду, і це є завершальним етапом облікового процесу.

Інформація внутрішньої управлінської звітність використовують в аналізі характеру витрат для дослідження позитивних та негативних факторів i тенденцій, що впливають на величину витрат та в підсумку сприяє підвищенню результативності (отримання максимального прибутку) фінансовогосподарської діяльності підприємства, дозволяє виявити нові джерела отримання прибутку. Прийняття результативних управлінських рішень починається 3 визначення мети і проблемних місць, які є у підприємства. Далі вихідна інформація обробляється і узагальнюється, на іiі основі приймається ефективне управлінське рішення для досягнення бажаних результатів розвитку бізнесу.

Аналіз беззбитковості підприємства $\epsilon$ ключовим моментом в прийнятті оперативних управлінських рішень. Метою аналізу та проведення аналітичних процедур щодо беззбитковості є розуміння того, як зміна рівня ділової активності підприємства вплине на кінцеві фінансові результати його діяльності. Точка беззбитковості - обсяг реалізованих товарів, який забезпечував би підприємству нульовий фінансовий результат - обсяг операцій, при якому сукупний дохід дорівнює сукупним витратам, тобто це точ- ка нульового прибутку або нульових збитків. Таким чином, знаходячись у точці беззбитковості підприємство ще не отримує прибутків, але вже не несе збитки.

Системою підтримки прийняття управлінських рішень щодо організації ведення бухгалтерського обліку та організації проведення аналізу ефективності розрахункових операцій з працівниками підприємства $\epsilon$ комп'ютеризована система, яка шляхом збору та аналізу великої кількості інформації може впливати на процес прийняття результативних рішень розвитку діяльності підприємництві. Новітні системи підтримки прийняття ефективних рішень виникли у результаті злиття управлінських інформаційних систем і систем управління базами даних, як системи, що максимально пристосовані до розв'язування задач щоденної управлінської діяльності, і є інструментом, щоб надати допомогу керівникам. На підприємствах використовуються бухгалтерські моделі системи підтримки прийняття рішень, що $\epsilon$ частиною програм Microsoft Access, Microsoft Excel та інших бухгалтерських програм, які є нині актуальними відповідно 3 вимогами чинного законодавства України.

Розробка системи бонусів для покращення настрою в колективі сприятиме росту продуктивності праці працівників підприємства. Заохочувальні інструменти на підприємстві, такі як преміювання, доплати й надбавки $є$ потужним мотиваційним заходом підвищення зацікавленості працівників в розвитку підприємства. Треба зазначити, що, 3 одного боку, розмір премії як засіб стимулювання робітників щодо ефективності їх праці в повній мірі знаходиться у взаємозв'язку від підсумків роботи компанії i, навпаки, підсумок господарської діяльності промислового підприємства залежить від практичної організації системи преміювання окремих категорій персоналу. Мотивація підлеглих збільшується, коли вони розуміють, що досягнення задач та цілей окремим підрозділом та підприємством в цілому, може допомогти їм у досягненні їх особистих цілей, також важливо завчасно чітко поінформувати персонал про виконання конкретного обсягу зобов'язань та задач, щоб отримати винагороду. Чималу роль у системі мотивації відіграє зворотній зв'язок, тому його важливо отримувати вчасно, щоб швидко відреагувати на наявні недоліки.

При стимулюванні працівників, які здійснюють функції управління, треба брати до уваги їх ініціативність, результативність, оперативність, об'єктивність, організаторські здібності, можливість ефективно використовувати приховані резерви підприємства, спроможність аналізувати, узагальнювати, творчо обмірковувати та використовувати на практиці сучасні досягнення науки, технологій та техніки. Так, доцільним $є$ переведення оплати керівників, службовців і певних фахівців на форму оплати праці за контрактом, що дозволить залучити та запобігти звільненню найбільш професійних, кваліфікованих, творчих i, насамперед, активних спеціалістів, гнучко регулювати чисельність та склад адміністративноуправлінського персоналу підприємства [8]. 
До ефективної організації обліку та контролю розрахунків з працівниками входять такі обов'язкові пункти, як вибір та впровадження на практиці усіх методів, способів та прийомів збору і обробки інформації, а також технічних засобів обліку й оргтехніки, які максимально відповідатимуть конкретно поставленим цілям та умовам.

Ключовим напрямом покращення організації бухгалтерського обліку розрахунків 3 персоналом $є$ автоматизація облікового, аналітичного й контрольного процесу, яка дозволяє виявити та запобігти значну кількість помилок при ручному веденні обліку [9].

Напрямки оптимізації тарифного регулювання витрат (суми заробітної плати), поліпшення мотиваційних заходів та механізму регулювання ефективності роботи підлеглих (оклад по відношенню до кваліфікаційного рівня), запровадження привабливих тарифних умов оплати праці як факторів збільшення мотиваційного (стимулюючого) значення тарифних систем, встановлення пропорцій тарифних ставок в залежності від значення кваліфікації підлеглих, удосконалення нормування як способу регулювання міри та оплати праці, впровадження гнучких форм і систем оплати праці дозволяє зменшити час на проведення облікових, аналітичних і контрольних процедур, а також зменшити кількість неавтоматизованих операцій.

Продуктивним методом поліпшення обліку є запровадження та проведення на підприємстві внутрішнього аудиту розрахунків за виплатами робітників. Не менш актуальним питанням є необхідність у відображенні точної та обгрунтованої інформації щодо виконання нормативів і динаміку економічних показників трудового потенціалу, постійний контроль за дотриманням співвідношення темпів зростання продуктивності праці та розміром заробітної плати, шляхи усунення невиробничих витрат, прихованих $\mathrm{i}$ явних збитків робочого часу та мотиваційні заходи (стимулювання праці на підприємстві) [10].

На базі цієї інформації проводиться регулярний контроль за використанням робочого часу на підприємстві, використання інноваційних технологій, дотриманням коректного співвідношення між приростом продуктивності праці та понесеними витратами на її оплату.

Висновки та перспективи подальших досліджень. Бухгалтерський облік розрахунків 3 оплати праці є фундаментальною частиною діяльності компанії, і правильність та достовірність відображення в обліку інформації про розрахунки з працівниками $є$ першочерговим завданням для управлінського персоналу підприємства.

В сучасних умовах розвитку економіки України достовірний облік витрат на оплату праці персоналу підприємства має бути не лише способом дотримання вимог чинного законодавства, а й джерелом надійної інформації для контролю та управління видатками на оплату праці. Нарахована заробітна плата підлеглим має безпосередньо залежати від ефективності роботи та росту продуктивності їх праці, під- вищення показників праці (кількісних і якісних), стимулювати розвиток підприємства в цілому та виробництва зокрема. Реформування оплати праці на базі суттєвих змін принципів іiі організації забезпечить основу мотиваційного механізму підвищення трудової активності працівників.

Заробітна плата визиває інтерес багатьох суб'єктів господарювання: підприємства 3 боку достовірності обліку, дотримання вимог законодавства та зниження розміру витрат, зменшення тиску на собівартість продукції; працівників - достатнього заохочення за виконану роботу (винагороди, премії, заробітна плата, тощо) та своєчасності виплат; податкової та фондів соціального страхування - достовірності проведення розрахунків сум нарахувань та утримань 3 фонду заробітної плати 3 урахуванням вимог чинного законодавства та своєчасності перерахування податків до бюджету держави.

Значення правильності та своєчасності обліку заробітної плати є вагомою частиною загального обліку на підприємстві, робота бухгалтера цього сегменту достатньо трудомістка, відповідальна та значуща. Допущення помилки в обліку при нарахуванні заробітної плати чи проведенні утримань та нарахувань призводить до низки помилок в підрахунках чи порушень чинного законодавства, що має суттєві наслідки для розвитку підприємства. Тому, бухгалтер 3 обліку заробітної плати повинен бути досвідченим, постійно вдосконалювати свої вміння та точно знати сучасні форми і системи оплати праці, безперервно слідкувати за змінами в законодавстві в сучасних реаліях мінливості.

Ведення обліку, як бухгалтерського так і податкового, щодо питань нарахування сум заробітної плати, нарахувань та утримань 3 неї обов'язкових податків, зборів та платежів грає суттєву роль в роботі бухгалтерів будь-якого підприємства. Так, це пов'язано насамперед зі ставленням до цього працівників підприємства, так як для них заробітна плата $€$ головним джерелом добробуту та існування. В свою чергу, суми, які спрямовує підприємство на виплату заробітної плати своїм робітникам визначають міру поповнення бюджету країни у розмірі податків та обов'язкових зборів з фонду оплати праці.

Отже, організація бухгалтерського обліку розрахунків $з$ оплати праці має забезпечувати точне та своєчасне нарахування сум заробітної плати відповідно діючих форм і систем оплати з урахуванням кількості, а головне якості витраченої роботи кожним працівником; коректний розрахунок сум нарахувань та утримань податків; постійний контроль за дисципліною працівників (обсяги використання часу, виконання ними норм виробітку); своєчасне виявлення та ефективне використання резервів для подальшого збільшення продуктивності праці; контроль витрат (фонд заробітної плати); безпомилкове нарахування i розподіл за напрямками нарахувань з сум заробітної плати на соціальне страхування та відрахувань до Пенсійного фонду України.

Ефективно організований облік розрахункових операцій $з$ персоналом щодо оплати праці в сис- 
темі управління підприємством призведе до його розвитку та розширення виробництва, а в кінцевому під - сумку отримання додаткового прибутку.

\section{Література}

1. Виплати працівникам: Положення (стандарт) бухгалтерського обліку 26: затв. Наказом Мінфіну від 28.10.2003 року № 601 за станом на 10.01.2012 p. URL: http://zakon.rada.gov.ua/laws/show/z1025-03 (дата звернення: 2.08.2018 p).

2. Черчик Л.М. Менеджмент персоналу : конспект лекцій. Луцьк : Східноєвроп. нац. ун-т ім. Лесі Українки 2013. 140 с.

3. Про оплату праці: Закон України від 24 березня 1995 року № 108/95-ВР за станом на 01.01.2017 р. Верховна Рада України. Київ. URL: http://zakon.rada.gov.ua/laws/show/108/95-\%D0\%B2\%D1\%80 (дата звернення: 2.08.2018 р.).

4. Інструкція про застосування Плану рахунків бухгалтерського обліку активів, капіталу, зобов’язань і господарських операцій підприємств і організацій: затв. Наказом Мінфіну від 30.11.1999 року № 291 за станом на 05.01.2018 p. URL: http://zakon.rada.gov.ua/laws/show/z0893-99 (дата звернення: 12.08.2018 p.).

5. Бутинець Ф.Ф. Бухгалтерський фінансовий облік: підручник. 8-ме вид., доп. і перероб. Житомир: ПП «Рута», 2009. 912 c. 2013. $688 \mathrm{c}$.

6. Садовська І.Б. Бухгалтерський облік: навч. посібник для вищої школи. К. : Центр учбової літератури,

7. Гарасим П.М., Журавель Г.П., Бруханський Р.Ф., Хомин П.Я. Первинний та аналітичний облік на підприємстві: навч. посібник. Тернопіль : АСТОН, 2005. 464 с.

8. Пушкар М.С. Фінансовий облік : підручник. Тернопіль : Вид-во «Карт-бланш», 2002. 628 с. $670 \mathrm{c}$.

9. Лишиленко О.В. Бухгалтерський облік : підручник. Київ : Вид-во «Центр учбової літератури», 2017.

10. Ткаченко Н.М. Бухгалтерський фінансовий облік, оподаткування і звітність : підручник. 2-ге вид., перероб. та доп. К. : Изд-во «Алерта», 2008. 926 с.

11. Мурашко M.I. Менеджмент персоналу: навч. посібник. [Електронний ресурc]. URL: https://pidruchniki.com/18421120/menedzhment/doplati_nadbavki (дата звернення 1.08 .2018 p.)

Стаття надійшла 14.08.2018 Стаття прийнята до друку 28.08.2018 Доступно в мережі Internet 17.10.2018

Васьковская Е.A.

кандидат экономических наук, старший преподаватель кафредра учета и аудита

E-mail: v.caterin17@gmail.com

Кохан E.A.

магистрант

кафредра учета и аудита

Одесская национальная академия пищевых технологий

ул. Канатная, 112, г. Одесса, Украина, 65039

E-mail: lenochka.kohan@gmail.com
Пчелянская Г.Б.

старший преподаватель кафедра учета и аудита E-mail: gaya_od@ukr.net

\section{УЧЕТ РАСЧЕТОВ ПО ОПЛАТЕ ТРУДА В СИСТЕМЕ УПРАВЛЕНИЯ ПРЕДПРИЯТИЕМ}

В статье рассмотрены особенности ведения бухгалтерского учета расчетов по оплате труда работникам предприятия с целью усовершенствования системы учета. Улучшение организации учета заработной платы для развития бизнеса осуществляется путем принятия эффективных управленческих решений. При этом большую роль играет достоверная, своевременная информация об объеме расходов на оплату труда персонала, поскольку значительную часть в себестоимости продукции занимают именно эти затраты.

Авторами приведены документы для ведения учета расчетов по оплате труда, проанализировано классификацию выплат работникам по группам, выделены показатели анализа эффективности труда для расчета экономических данных, таких как уровень обеспеченности предприятия рабочей силой и среднего размера заработной платы работников и производительности их труда. 
Рассмотрены законодательные акты, регламентирующие порядок ведения учета заработной платы на предприятии, приведена характеристика счета, предусмотренного планом счетов, для учета расчетов по выплатам работникам.

Проанализировано, что в современных условия компьютеризированная система учета путем сбора и анализа большого количества информации может влиять на процесс принятия результативных решений развития деятельности предприятия, а также позволяет выявить и предотвратить значительное количество ошибок в отличии от ручном ведении учета.

Изучены поощрительные инструменты на предприятии, такие как премирование, доплаты и надбавки является мощным мотивационным стимулом повышения заинтересованности работников в развитии предприятия.

Сделаны выводы, что для эффективного развития предприятию необходимо детально изучать структуру затрат на оплату труда, стимулировать заинтересованность работников (мотивационные мероприятия) для повышения производительности их труда, контролировать темпы роста размера заработной платы по отношению к росту производительности труда, внедрять автоматизации бухгалтерского учета на предприятии.

Ключевые слова: учет, заработная плата, расходы на оплату труда, внутренняя управленческая отчетность, мотивация работников, автоматизация процесса.

\author{
Vaskovska K. \\ Ph. D., Assistant \\ Pchelianska $\mathrm{H}$. \\ Assistant \\ Department of Accounting and Auditing Department of Accounting and Auditing \\ E-mail: v.caterin17@gmail.com \\ Kohan $\mathrm{H}$. \\ Undergraduate \\ Department of Accounting and Auditing \\ Odessa National Academy of Food Technologies \\ Kanatna str., 112, Odesa, Ukraine, 65039 \\ E-mail: lenochka.kohan@gmail.com
}

\title{
ACCOUNTING OF THE LABOUR PAYMENT IN THE MANAGEMENT SYSTEM OF THE ENTERPRISE
}

In the article the peculiarities of the accounting of the labour payment of employees of the enterprise in order to improve the accounting system have been considered. Improvement of the accounting the organization of the salary for business development is carried out through the acceptance of the effective management decisions. At the same time, reliable and timely information about the amount of expenses for the payment of the labour plays an important role as precisely these costs occupy the significant part of the cost of production.

The authors give the documents for the accounting of the labour payment, the classification of employee payments by groups has been analyzed, indicators of labour efficiency analysis to calculate economic data have been pointed out, such as the level of the enterprise provision with labour force and the average salary of the employees and their labour productivity.

Legislative acts regulating the procedure for accounting for salary at the enterprise have been considered, the characteristics of the account provided by the chart of accounts, for accounting of the employee payments has been given.

It has been analyzed that in modern conditions computerized accounting system by collecting and analyzing the large quantity of the information can influence the process of making the effective decisions about the development of the enterprise's activities, and also can allow to identify and to prevent the significant number of the errors, in contrast to the manual accounting.

The authors have studied the incentive tools at the enterprise, such as bonuses, surcharges and extra payments which are the powerful motivational incentives for increasing the employees' interest to the enterprise development.

It has been concluded that for effective development of the enterprise, it is necessary to study in detail the structure of the labour costs, to stimulate employees' motivation (motivational measures) for increase their labour productivity, to control the growth rate of the salary with respect to the growth productivity, and to introduce accounting automation at the enterprise.

Key words: accounting, salary, labour costs, internal management reports, employee motivation, automation of the process. 


\section{References}

1. Vyplaty pratsivnykam: Polozhennia (standart) bukhhalterskoho obliku 26: Zatv. Nakazom Minfinu vid 28.10.2003 roku № 601 za stanom na 10.01.2012 r. (2012). Retrieved August 2, 2018, from http://zakon.rada.gov.ua/laws/show/z1025-03

2. Cherchyk, L. M. (2013). Menedzhment personalu. Skhidnoievrop. nats. un-t im. Lesi Ukrainky.

3. Pro oplatu pratsi: Zakon Ukrainy vid 24 bereznia 1995 roku № 108/95-VR za stanom na 01.01.2017 r. (2017). Retrieved August 2, 2018, from http://zakon.rada.gov.ua/laws/show/108/95-вp

4. Instruktsiia pro zastosuvannia Planu rakhunkiv bukhhalterskoho obliku aktyviv, kapitalu, zobov'iazan i hospodarskykh operatsii pidpryiemstv i orhanizatsii: Zatv. Nakazom Minfinu vid 30.11.1999 roku № 291 za stanom na 05.01.2018 r. (2018). Retrieved August 12, 2018, from http://zakon.rada.gov.ua/laws/show/z0893-99

5. Butynets, F. F. (2009). Bukhhalterskyi finansovyi oblik (8th ed.). Zhytomyr: PP «Ruta».

6. Sadovska, I. B. (2013). Bukhhalterskyi oblik. Kyiv: Tsentr uchbovoi literatury.

7. Harasym, P. M., Zhuravel, H. P., Brukhanskyi, R. F., \& Khomyn, P. Ya. (2005). Pervynnyi ta analitychnyi oblik na pidpryiemstvi. Ternopil: ASTON.

8. Pushkar, M. S. (2002). Finansovyi oblik. Ternopil: Vyd-vo «Kart-blansh».

9. Lyshylenko, O. V. (2017). Bukhhalterskyi oblik. Kyiv: Vyd-vo «Tsentr uchbovoi literatury».

10. Tkachenko, N. M. (2008). Bukhhalterskyi finansovyi oblik, opodatkuvannia i zvitnist (2nd ed.). Kyiv: Yzdvo «Alerta».

11. Murashko, M. I. Menedzhment personalu. Retrieved August 1, 2018, from https://pidruchniki.com/18421120/menedzhment/doplati_nadbavki

Received 14 August 2018 Approved 28 August 2018 Available in Internet 17.10.2018

Цитування згідно ДСТУ 8302:2015

Васьковська К.О., Пчелянська Г.Б., Кохан О.О. Облік розрахунків з оплати праці в системі управління підприємством // Економіка харчової промисловості. 2018. Т. 10, Вип. 3. С. 66-72; doi: 10.15673/fie.v10i3.1063

Cite as APA style citation

Vaskovska, K., Pchelianska, H., \& Kohan, H. (2018). Accounting of the labour payment $n$ the management system of the enterprise. Food Industry Economics, 10(3), 66-72 ; doi: 10.15673/fie.v10i3.1063 